\section{Influence of collective wine marketing on hungarian wine sector}

\author{
Zoltán Szakál \\ College of Nyíregyháza \\ szakal@nyf.hu
}

\section{SUMMARY}

Nowadays, the importance of marketing is increasingly obvious. The number of those who apply those possibilities and methods provided by the marketing with which more efficient operation and higher amount of profit can be obtained is increasing. Special marketing fields have appeared that make the marketing characteristics of the single trades, product groups and industrial branches are widely known and utilized. During the more than 10 years following the changes of regime, the Hungarian wine market underwent a huge change. It is obvious, that this process has not stopped, and further market rearrangements may be claimed. The product and price policies have changed. Out of the marketing mix elements, mostly the marketing communication has changed, and the costumer has come to the centre. This marketing approach resulted in the formation of the newly established Hungarian Wine Marketing Public Benefit Company. The common marketing activity of the organization should have positive impacts on the industrial branch, although its efficient operation still has hindrances.

Keywords: wine marketing, wine consumers, collective marketing, distributions of wine trade

\section{INTRODUCTION, OBJECTIVE}

Under present market circumstances, the application of wine marketing is essential condition for a wine-grower and wine-merchant to be able to stay in the market and produce profit on the long term. Those, who are not able to keep abreast of the market challenges, will drop behind and shall close their wineries. Many articles have been published on wine marketing which only write down its necessity. The effective marketing requires such conditions which are not yet available in Hungary. It is very difficult to find common interests on the distributed market. The Hungarian wine culture and wine market will only emerge to the required level if the common interest bases on appropriate professional and social consensus. Competence would play an enormous role, however it is not always complete. The aim of the present article is to draw attention to the problems and to provide a transparent situation analysis on the domestic situation of wine marketing.

During the last years, the interest for wine has increased. It is fashionable to know the wines; the number of people who like the quality and special wines is increasing. At the same time, there is a considerable demand for the cheap but good quality bottled wines which are purchased at the most different places by people.

However, the experience shows that the knowledge of the market and the consumers are not satisfactory both at company and collective level.
The interest-promotion of the industry is weak, and it has no strategy for the future.

\section{MARKETING AND WINE MARKETING}

The EU accession is accompanied with the larger market and all of its advantages and disadvantages. Companies have to measure themselves with competition challenges and many competitors. Nothing can be taken against this process, so our attitude and way of thinking have to be changed. The customers enjoy the rich and affordable supply, and besides the Hungarian wines they also take the foreign ones as novelties off the selves (Kárpáti, 2006).

We should rather emphasize our advantages than our competitors' disadvantages. In the Hungarian wine industry, there would be a great demand for the cooperation of the domestic producers in order to prevent the foreign competitor utilizing the domestic quarrels, as the laughing third party, and capturing the market. It is advisable to become acquainted with both the domestic and foreign competitors, and learn and seize upon ideas from them. Nevertheless, we should be fully aware of our own product's market value and we must not allow to be hurried into price competition. Not only the price should be the single measure of value but the quality, and the price should be assigned to it. It should be emphasized for the customers that they will be satisfied with our product as well as with other's and it is advisable to reason it as well (Tonk, 2005).

Among the objectives of the economy, tourism and not least the oenologists and people dealing with wine, the correspondence of their products and services with the European Union are high-ranked (Szmilkó, 2006).

Many wine-growing companies suffer from the lack of financial resources in consequence they are not able to perform effective marketing activity. The collective marketing can not replace the companylevel marketing tasks but could help in the collection, processing and distribution of information which mean the basis for market establishment. In the case of wine, the collective marketing was less effective, among other things because small amount, altogether annually 300-400 million HUF was spent on it and part of the programmes was not served marketing objectives. The act on agricultural marketing, which would allocate appropriate amounts for the activities, has not been codified for years. The available small amount of financial resource should be used more effectively, hubs have to be created regarding the objectives, tools and resources, the different products have to be represented distinctively and they have to 
be communicated in a continuously harmonised way (Totth, 2005).

Besides the facilitation and coordination of tourism investments, the most important task may be the organisation of joint marketing actions and titled thematic events both for professionals and the public. In every project the expenditures and the results must be in harmony with each other, that is a minimum required increase of the result has to belong to a certain amount of expenditure.

The role of the brand is to differentiate the products from each other as much as possible, but at the same time keep them in one group and give instructions for the consumer. The brand could strengthen and integrate the assortment and the marking of geographical origin.

The organisation of wine-contests, where only those wines could be evaluated by the jury which have achieved first rank (golden medal) at a dignified national competition, is an excellent opportunity for emphasizing the quality. The quality is emphasized by the bottle-label made directly for this wine.

The marketing communication could basically be divided into five main areas: promotion, sales promotion, personal selling, PR (public relations) and direct marketing. The objective of applying these elements is to influence the market, change advantageously the consumers' behaviour, and increase the customers' willingness (Szmilkó, 2006).

In the case of wine advertisements, it is more difficult to create a message for the product than it is in the case of advertisements of other beverage. The essence of the efficiency of wine advertisements is how the amount and characteristic of the product could be proportioned to the size and cost of the advertisement.

Trade transactions have been carried out through the internet since 1990 in which successes and setbacks have equally happened. The internet is a short and modern marketing channel. It is easy to launch a new product through a webpage of a company established with relatively small investment (the annual cost is approximately 20.000 HUF), it could be achieved from all over the world during the whole day, and so it makes a world-wide presence possible. The operation of the web market is relatively cheap and quite effective solution with adequate technical tools. Keeping touch with the consumers is more effective and more direct. From the consumers' point of view, it is also a comfortable solution because there is no closing hour, there is ample choice, they could save time and fatigue during hunting out the certain product. Its disadvantage is that the customer could not taste the product and people are still accustomed to finger and physically test the product when buying it (Eszes, 2005).

\section{WINE CONSUMERS}

In Hungary, the following groups of wine consumers could be detected:

- Customers consuming quality wine: The "quality" refers to both the consumed wine and the customer's attitude towards the wine.
- Intellectual wine consumers: They usually choose bottled quality wines. When choosing wine, the most important factor is the type, and then comes the quality and the habitat.

- Elite consumers: Besides people with university degree, all the medium-level and top-managers belong to the group of elite consumers. In line with the previous group, they prefer the bottled quality wines. They mostly drink wine when they eat.

- Group of youth: They mainly drink wine with their friends and rarely when they eat. Among their motivations there is the cultured way of wine consumption and they like to refer to the medical impacts of the wine as well. They would rather discover the alcohol in the wine than the gastronomic delight, but more than the average think that the wine is part of the culture.

- Consumers living in villages: Most of their wine consuming habits do not differ from the average, but considering the quality and packaging of the wine some particularities could be found, they more frequently drink table and flowing wine.

- Consumers of liquor stores: Liquor store consumers are those who buy or drink wine in liquor stores or pubs.

- People who do not consume wine (Hajdu and Botos, 2005).

The wine consumer is an interesting stuff because it is difficult to understand why they buy what and what they really require. Companies applying the classical technologies and laws, in the different vintages produce different products; so it could not be said about wine that it has the same taste and harmony in every year. In the case of beers, this problem can not be detected and due to the quicker rotation speed it could be traded with larger profit margin - and even the consumer comes off well. The wines of the "New World" (Australia, Chile, SouthAfrica, etc.) are much more balanced during the single vintages. In these areas, even the dripirrigation is allowed, so the technological regulation makes much greater opportunities possible. Of course, it does not mean that this regulation is not strict. The fact of the matter is that the end-product should be of excellent quality and the customer should be willing to purchase and consume it.

The oenologist using consciously their professional knowledge is able to produce such wine which they imagined before the vine-harvest. If the oenologist knows the requirements of the consumer (tastes, colours, etc.), they are able to produce that wine. But in the majority of the cases, it is not enough, because the product has to be delivered to the consumer. The product should be available at a time when the consumer requires it and has money for it. Wine marketing helps the oenologist better understanding their consumer target group and influencing (helping) the customer during the purchasing process. For all of this, however, a well coordinated, cost-saving and effective marketing activity is required. 


\section{COLLECTIVE WINE MARKETING}

60 percent of the issue expenses which is 8 HUF per litre and which provides the basis of the collective wine marketing has to be spent on the elaboration and implementation of the wines' collective marketing programme (wine marketing) (the amount of the previous wine revenue according to professionals' estimation is a total 1.5 billion HUF). The implementation of the basically good initiative however leaves much to be desired. While according to the opinion of the wine-growers the Hungarian Wine Marketing Public Benefit Company would be the appropriate institution for the management of the payment, the EU does not classify the Public Benefit Company as a paying office. As a balancing solution the competent minister proposed the Agricultural Marketing Centre for this task. Its reason is that the realized payments would be state aids as it is a state income. This makes the revision of the law or the achievement of the Collective's approval necessary. Rationally, the EU is not interested in the implementation of collective wine marketing tasks applying to Hungary, because the wine-lobby is quite strong, and the Hungarian wine could create dangerous competitive situation for the partner countries. On the other hand, the wine production within the EU - despite the restrictions still shows the signs of overproduction. The bases of the National Wine Strategy have already been born for the 2007-2022 period, but this strategy is based on the incomes derived from the issue expenses. Central part of the strategy is to improve the competitiveness of the wine which is expanded not only for the EU but the newly opening Eastern (Russian, Ukrainian) markets as well (EU-info, 2005).

Collective wine marketing would mean a wine marketing strategy deriving from the consumer's requirements and basing on it, where the objective is the permanent maintenance of the consumer's faith and the positive influence of the purchasing mechanism in connection with the products of the collective. It is necessary to elaborate a common communication which will create the basis of strengthening the positive image at home and will contribute to its establishment abroad. Only this could lead to that most important objective that the consumption of the Hungarian wines should increase.

\section{PRINCIPLES OF THE NATIONAL WINE MARKETING STRATEGY}

- The National Wine Marketing Strategy (NWMS) builds upon the already present production, market, legal and economic environment of the industry.

- The NWMS has to represent the Hungarian Wine, the whole industry.

- The role of the NWMS is the wide-scale influence of the national grape- and wine-production and the wine market.
- From market points of view, the Strategy has two main roles: increasing the value of the wine consumption and improving the competitiveness of the Hungarian wine both in Hungary and abroad.

- The effectiveness of the NWMS depends on the concentration of the used tools. The target markets should be chosen taking the fact into account that there will be non-satisfied requirements and "unsupplied areas".

- The implementation of the programme is market and within this segment oriented.

- The NWMS actively plays both towards the domestic market and the export.

- The domestic and foreign programmes must be represented in 50-50 percent.

- On foreign markets 3-5 main markets, marketgroups should be determined and focused marketing activity should be performed.

- In order to implement the programmes, the foreign examples should be known and their results should be utilised to the necessary degree.

- Based on the Strategy, focused activity of national importance and finance is carried out to which local programmes and programmes with sectoral impact may as well connect.

- The result of the Strategy means increased demand for every market actor.

- The evaluation of the programmes happens in at least five-year periods.

- The programmes and knowledge on their implementation get two-level publicity from professional and administrative points of view.

- The Strategy plays a role not only in creating the image of the Hungarian wine but in creating the image of Hungary as well.

- Co-operation with other, non-industrial programmes bearing on the wine sector, finding the synergy: wine and health, wine and tourism, wine and gastronomy, wine and culture, etc. (Bormark, 2006).

The Strategy determines the priority of the following markets and market groups:

- British market: great expenditure - large international impacts pointing beyond the market.

- Market of North-America: great expenditure significant impact, or local expenditure - local result.

- Germany and the BENELUX states: traditional market, quality and improvement of market positions - local impact.

- Markets of Eastern-Europe: reconstruction of the market, significant expenditure - significant quantitative increase.

- Market of the Scandinavian countries: monopolized trading, small expenditure localized impact.

- Far East: early stage of market establishment, great expenditure - long-range return and impact (Harsányi, 2005). 


\section{CONCLUSIONS DEDUCED FROM INDIVIDUAL EXPERIENCES}

Presently 4 different types of marketing activity can be noticed at 4 levels in relations with wine marketing. These four levels are summarized in Table 1. The absolute lack of both regional and winedistrict wine marketing can be observed. The listed ones are those who carried out spectacular and real marketing activity during the past years. A rank can be seen as well which refers to the effectiveness of the marketing activity and the achieved results. Although, the single wineries followed individual actions and strategies, however they could address huge audience. The individual non-profit organisations, e.g. the Hungarian Grape and Wine Culture Public Benefit Company, the House of Hungarian Wines and other similar organisations, organised such events which moved both the consumers and the illustrious representatives of this profession. They organised conferences, exhibitions, demonstrations, fairs, and wine-contests. It could be well noticed in the single market researches that most of the people are still regular televiewers and media-watchers. In many televisions, programmes relating to wine are more often broadcast which also attract attention and influence the consumer attitude of people buying wine to a large extent.

The following, more considerable marketing activity materialized mainly in publications belongs to the Hungarian Tourism Co. The really colourful, attractive, short prospectuses containing informal data and pictures and published in more languages are acceptable and very effective in the case of both the domestic and the foreign guests and interested people.

Organisations situated on the last place of the hierarchy, but regarding their importance and different objective deserve special judgement are the Agricultural Marketing Centre Public Benefit Company (AMC) and the newly established Hungarian Wine Marketing Public Benefit Company. These organisations perform collective wine marketing activity. It also means that such marketing activity has been carried out on foreign markets that has provided advantages for the Hungarian wine market and the image of the country.

More significant wine marketing activities in Hungary

\begin{tabular}{|c|c|c|}
\hline 1 & Wineries, wine-merchants & Consumer attracting, own winery strengthening \\
\hline 2 & NGOs dealing with wine & $\begin{array}{c}\text { Thematic, event-specific, conferences, exhibitions, fairs, wine- } \\
\text { contests }\end{array}$ \\
\hline 3 & Wine programmes in the media & Propagative, collective marketing level \\
\hline 4 & Hungarian Tourism Co. & Tourism-type marketing, coloured, informal prospectuses \\
\hline 5 & AMC, Hungarian Wine Marketing Public Benefit Company & $\begin{array}{c}\text { Collective marketing, foreign propagation of the Hungarian } \\
\text { wines }\end{array}$ \\
\hline
\end{tabular}

Apart from the listed ones, many smaller or bigger organisations are trying with wine marketing activity but their results fall behind the expectations.

The marketing communication and strategy could be effective if we exactly know who belongs to our target groups. It is a strategic decision in how many segments a company tries to perform marketing activity. The possible directions and consumer groups are summarized in Figure 1. The task of the collective marketing activity is the popularization and the widening of possibilities. The National Wine Strategy decides on how many fronts (domestic market, foreign market, final consumer, organisational customer) and with how much emphasize we should be present. In comparison with the possibilities of the country, the presence and marketing activity in the neighbouring countries would be effective. From the farer cultures, the Scandinavian countries and the Far-East countries could be the primary target groups. Some 80 percent of the more hundred million HUF that will be available should be spent on marketing in foreign markets. $20 \%$ should be spent on the popularization of domestic wines supposing that the already existing market communication channels connected to wines still operate.
Anybody can be successful in the wine market, if they know which way shown in Figure 1 they will go along. This decision necessarily supposes that the required capital, capacity, liquidity and other things are available to do so.

Figure 1: Distribution of consumers and the ways of wine trading on the wine market

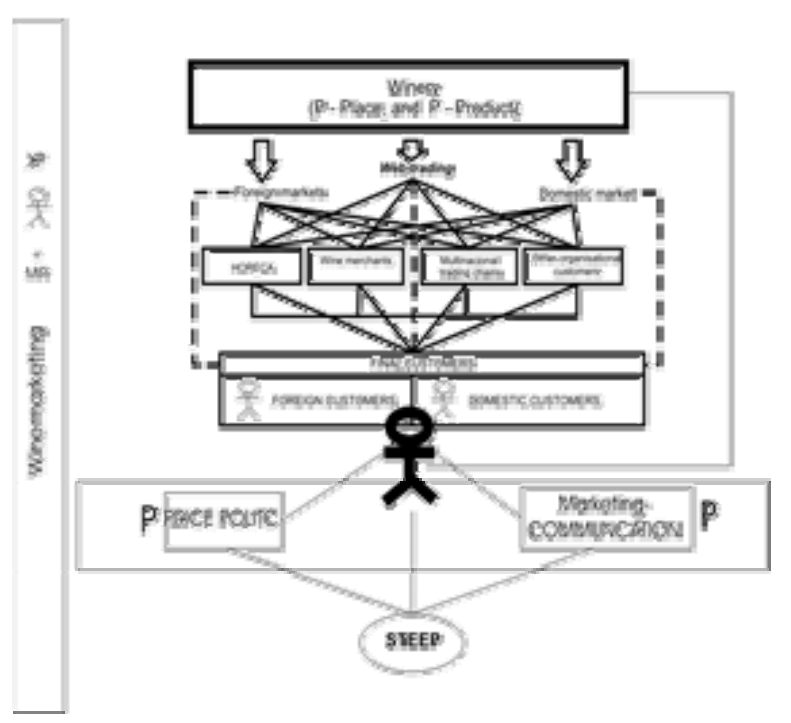


The role of the HORECA (hotels, restaurants, and cafés), the wine-merchants and the other organisational customers is significant.

Here belong the hypermarkets as well, where significant part of the wine trading happens.
Both the bigger companies and the small- and medium-size enterprises could successfully close their year of production if they take the advantages of marketing. It requires conscious marketing activity.

\section{REFERENCES}

Eszes, I. (2005): Borok a világhálón, Kertészet és szőlészet 4, Magyar Mezőgazdaság Kiadó, Budapest

Hajdu, I.-Botos, E. P. (2004): Bormarketing, Mezőgazda Kiadó, Budapest

Harsányi, G. (2005): Borászatok versenyképessége, TDK, Budapest

Kárpáti, L. (2006): Európai uniós projektek pénzügyi menedzsmentje, Szaktudás Kiadó Ház Rt., Budapest

Piskóti, I. (2003): Miskolci Egyetem MI bormarketing szakmai tanácskozás
Szmilkó, G. (2006): Bormarketing alapok, Borászati füzetek 3, Magyar Mezőgazdaság Kiadó, Budapest

Tonk, E. (2005): Versenytársak, ügyfelek, Kertészet és szőlészet 4, Magyar Mezőgazdaság Kiadó, Budapest

Totth, G. (2005): Beteg bormarketing, Kertészet és szőlészet 4, Magyar Mezőgazdaság Kiadó, Budapest

Internet 1: http://www.eu-info.hu/cikk.asp?db=hirek\&id=6135, 2005

Internet 2: www.bormarketing.hu , 2006. 